\title{
Study of Vermicompost and Vermiwash Produced from Cow Manure and Rice Bran Waste on the Physiological Growth of Abelmoschus esculentus L.
}

\author{
Priyesh Kumar Gupta ${ }^{2}$, Ajay Kumar Singh ${ }^{1 *}$, Jane C. Benjamin ${ }^{3}$, Harison Masih ${ }^{3}$, \\ Ankit Singla ${ }^{4}$, Surendra Kumar Ojha ${ }^{2}$ and P.W. Ramteke ${ }^{5}$ \\ ${ }^{1}$ Department of Food Process Engineering, SHUATS, India \\ ${ }^{2}$ Agriculture Microbiology SHIATS, Allahabad, Uttar Pradesh, India \\ ${ }^{3}$ Department of Industrial Microbiology, SHUATS, India \\ ${ }^{4}$ Regional Centre of Organic Farming, Ministry of Agriculture \& Farmers Welfare, \\ Bhubaneswar, Govt. of India \\ ${ }^{5}$ Department of Biological Sciences, Sam Higginbottom University of Agriculture Technology \\ \& Sciences, Allahabad, India \\ *Corresponding author
}

\section{A B S T R A C T}

Vermicomposting is a cost-effective and eco-friendly process used to treat organic waste. Vermicompost is nutrient rich organic compost with active microorganisms resulting from

\section{Key words}

Vermicompost, Vermiwash, Rice bran, Eisenia foetida, Okra

Article Info

Accepted:

10 July 2018

Available Online:

10 August 2018 the interaction between earthworm and microorganisms on the breakdown of organic matter. Earthworms convert the waste material in to small particles by breaking in the gut of earth worm obtaining nutrients from the microbes that harbor on them. These processes increase the rate of degradation of the organic waste matter, modify the physico-chemical properties of the waste materials and forms humus in which unstable waste matter is completely oxidized. Vermiwash is a biofertilizer that enhances growth in Okra plants. Vermiwash was extracted from vermicompost composted from rice bran through earthworms (Eisenia foetida). It was observed that treatment of vermiwash significantly increased the growth of Okra plants. The significant growth was observed in okra plant height $89.66 \pm 1.3 \mathrm{~cm}$. This study showed that combination of organic fertilizers, Vermicompost and vermiwash when compared with control greatly influenced okra plants growth parameters. Among the five treatments, Treatment $\mathrm{T}_{3}$ (Soil + vermicompost $+{ }^{1} / 2$ recommended dose of NPK) was most effective for all growth parameters of okra. In the present study vermicompost and vermiwash are a plant growth promoting organic fertilizers that efficiently improve the growth of okra.

\section{Introduction}

Okra, Abelmoschus esculentus [L.] Moench is a dicotyledonae, belonging to the order Malvales, family Malvaceae and genus
Abelmoschus, syn. Hibiscus, (Schippers, 2000). It is an important vegetable crop widely grown in the tropical and subtropical regions worldwide (Tindall, 1983). Okra plant is a robust, erect, annual herb, its height ranges 
between 1 to $2 \mathrm{~m}$, with simple leaves. Its edible fruits about $100 \mathrm{~g}$ that contains about 81 $\mathrm{ml}$ water, 56 calories, $11 \mathrm{~g}$ carbohydrate and $4.4 \mathrm{~g}$ protein. Mature seed of $100 \mathrm{~g}$ okra contains $20 \%$ edible oil and $20.23 \%$ crude protein due to high lysine content and it is a good source of vitamin C (Berry et al., 1988). Okra is particularly rich in calcium and ascorbic acid. Okra fruit is useful medicinally, in curing ulcer and suppressing the pains and effects of haemorrhoid. The mucilage has been used as a plasma replacement or blood volume expander (Siemonsma and Kouame, 2004).

Vermicomposts are rich in bacteria, actinomycetes, fungi (Edwards, 1983; Tomati et al., 1987) and cellulose degrading bacteria (Werner and Cuevas, 1996). The use of organic matter such as animal manures, human waste, food wastes, yard wastes, sewage sludge and composts has long been recognized in agriculture as beneficial for plant growth and yield and the maintenance of soil fertility. Composted organic material is being applied on agricultural fields as an amendment to provide nutrients and also to enhance the organic matter content and improve the physical and chemical properties of the cultivated soils. It contains essential nutrients for plant growth, especially $\mathrm{N}$ and $\mathrm{P}$ (Beltran et al., 2002). The use of organic amendments, such as traditional thermophilic composts, has been used to increase crop productivity and yields (Bwamiki et al., 1998), and their use is usually associated with improved soil structure and enhanced soil fertility (Follet et al., 1981), increased soil microbial populations (Barakan et al., 1995) and activity (Zink and Allen, 1998; Pascual et al., 1997), and an improved moisture-holding capacity of the soil. Vermicomposts are finely divided peat-like materials with high porosity, aeration, drainage, water-holding capacity and microbial activity, which make them excellent soil amendments or conditioners (Edwards and Burrows, 1988; Atiyeh et al., 1999). Vermicompost could be used as an excellent soil amendment for main fields and nursery beds and has been reported to be useful in raising nursery species plants. In nature, sometime plants follow altered growth patterns such as negative geotropism of roots, stem elongation and dwarfing, shortening of vegetative phase, enhancement of leaf area, photosynthetic rate, flowering and fruiting by matured plants. Vermicompost could promote early and vigorous growth of seedlings (Edwards, 1988).

Vermiwash is the watery extract of Vermicomposts, extracted in the presence of rich population of earthworms. It contains several enzyme, plant growth hormones, vitamins along with micro and macro nutrients (Shield and Earl, 1982) which increases the resistance power of crops against various diseases and enhance the growth and productivity of crops (Anand et al., 1995), Karuna et al., 1999). The treatment of vermiwash of vermicompost has been shown to reduced disease by necrotrophs as well as biotrophs (Al-Dahmani et al., 2003) and significantly decreases in soil borne pathogens and various pests (Nakasone et al., 1999). Generally, foliar spray of vermiwash and vermicomposting would off era method of supplying nutrients to higher plants more rapidly than methods involving soil and root application (Marschner 1995). In dry condition with a lack of water in the top soil and corresponding decline in nutrients available foliar application of nutrients is much more effective than soil application (Grundon 1980). Foliar spray containing nutrients can also compensate for the decline in nutrients uptake by roots with the onset of the reproductive stage a result increase in number of fruit (Buckerfield et al., 1999). It was demonstrated that growth of ornamental plant after adding vermiwash showed similar growth patternas with addition of auxines, 
gibberellins and cytokinin as through the soil (Grappelli et al., 1987).

Earthworms are tubular creature of somewhat lower evolutionary status than insects. An earthworm is a tube-shaped, segmented worm found in the phylum Annelida. They are commonly found living in soil, feeding on live and dead organic matter. Its digestive system runs through the length of its body. It conducts respiration through its skin. An earthworm has a double transport system composed of coelomic fluid that moves within the fluidfilled coelom and a simple, closed blood circulatory system. The species Eisenia fetida (Monroy et al., 2006) are commonly used globally for the management of organic wastes, and also in ecotoxicology, physiology and genetics studies. Survival, reproduction and growth of earthworms can be critically affected by environmental conditions. Studied the influence of temperature, moisture content, ammonium content, population density, type of food, intra- and inter-specific competition on the life histories of four earthworm species most extensively used in vermicomposting (Eisenia festida) (Domínguez et al., 2004 and Edwards and Burrows, 1998). The use of earthworms for the biodegradation of organic wastes has been reported to be a positive development in the biological waste management (Graff, 1981). The epigeic earth worm Eisenia foetida has been extensively used to produce vermicompost from different plant residues, city refuse and sewage sludge because of its rapid growth rate, early sexual maturity and extensive reproduction (Carmody and Collier, 1979). Reported that D. veneta, Eudrilus eugenia, $P$. excavates and $P$. hawayana and Eisenia foetida to be the most capable earthworms to breakdown the organic refuse.

Vermicompost is a mesospheric biodegradation product from earthworm and microorganisms. Such as bacteria, actinomycetes, fungi and celluase degrading bacteria. Vermiwash is the watery extract of Vermicompost containing enzyme, plant growth hormones, and vitamins along with micro and macro nutrients, which increase the resistance power of crops. In view of the above facts, the present study was conducted to assess the effect of vermicompost and vermiwash produced from rice bran waste on the growth of okra.

\section{Materials and Methods}

\section{Place of work}

The present study was conducted at the Post Graduate Laboratory, Department of Microbiology and Fermentation Technology, Jacob School of Biotechnology and Bioengineering, SHIATS, Allahabad, U.P.

\section{Collection of wastes}

Agro waste (Rice bran) was collected from market of Allahabad districts and manure was collected from the Sundaresan School of Animal Husbandry and Dairying, SHIATS.

Partially decomposed mixture of cow manure and agro wastes were used for enhancement of vermicomposting efficiency. After the collection, the organic wastes and manure were exposed to sun light for 3 days to remove the various harmful organism and noxious gases.

\section{Collection of earth worm}

Earth worms, Eisenia foetida species was collected from Krishi Vigyan Kendra, SHIATS, Allahabad. The collected earthworms were cultured under laboratory conditions. The temperature was maintained between 20 to $30^{\circ} \mathrm{C}$ and moisture was maintained upto $40 \%$ to $60 \%$ (w/w) for proper growth and survival of earthworms. 


\section{Experimental setup for vermicomposting}

The experiment of vermicomposting was carried using Plastic containers. The combination of cow manure, rice bran and soil were used in 1:1:1 ratio for each vermicompost container. Vermicompost containers were moistened and inoculated with $1 \mathrm{~kg}$ of culture Eisenia foetida. The bed was covered with waste jute bags. The bed was moistened daily from 01 to 45 days for maintaining the moisture content and after one week interval the mixture of bed was turned manually. After 45 to 50 days granular, brownish vermicompost appeared on the upper surface of vermicompost beds. The vermicomposts with earthworms were used for extraction of vermiwash (Plate 3.2).

\section{Extraction of vermiwash}

Vermiwash was extracted from vermicompost using vermiwash collecting device (plate 2.3). The apparatus was made from plastic drum having capacity of 20 litters and a tap at the bottom. The drum was filled with stones or broken particles (about $10 \mathrm{~cm}$ thickness) followed by sand layer (2-3 cm thickness) and lastly filled with vermicompost with heavy population of earth worms. Simultaneously fresh water was added to the drum.

The watery extract of vermicompost was drained off drum from the drum and collected in plastic container. The colour of vermiwash extract was yellowish to black. The process of extraction was completed in 2-3 days and then used for foliar spray of okra crop (Plate 2.3).

\section{Treatment schedule}

Treatments of vermicompost on okra plants were triplicated. One replicate was assigned for foliar spray of Vermiwash. The triplicates (R1, R2, and R3) followed for all treatments were as:
$\mathrm{T}_{0}-$ Normal Soil (control); $\mathrm{T}_{1}-$ Soil + Vermicompost (1:1); $\mathrm{T}_{2}-$ Soil + NPK (Recommended dose-(120:60:60kg/ha); $\mathrm{T}_{3}-$ Soil $+1 / 2$ recommended dose of NPK + Vermicompost; $\mathrm{T}_{4}-$ soil $+1 / 2$ recommended dose of NPK + Vermiwash; $\mathrm{T}_{5}$ - soil + Vermiwash.

\section{Experimental design}

The growth experiments for the different treatments of vermicompost as well as vermiwash on the Okra crop were conducted in earthen pots. The seeds of the Okra were directly sown in it. After 7 days germination percentage was observed in each pot. After 10 days, thinning of the okra seedling was done in each pot. Pots were irrigated daily on the Okra crop. Growth readings (plants height and Number of leaves) were observed every 15 days upto 75 days. Leaf area was also determined after 75 days of plant growth.

\section{Growth measurement of okra plant}

The growth of Okra plant (plant height and number of leaves) due to different treatments vermicompost was recorded (Plate 2.4).

\section{Results and Discussion}

Effect of various treatments of Vermicompost and Vermiwash on Seed germination (\%) of Okra (Abelmoschus esculentus $\mathrm{L}$.) plant after 7 days

The present study was conducted to evaluate the seed germination percentage of okra plants for different treatments of vermicompost and vermiwash. In the present investigation the soil was mixed with vermicompost (1:1) treatment $T_{1}$ and treatment $T_{3}$ (soil mixed with $1 / 2$ recommended dose of NPK). The treatments $\mathrm{T}_{4}$ contained soil and vermiwash mixed with $1 / 2$ of recommended dose of NPK. Treatment $\mathrm{T}_{5}$ contained only soil and vermiwash. Based on the observation made 
after one week the seed germination improved in each treatment containing vermicompost or vermiwash in comparison to the treatment $\mathrm{T}_{0}$ (containing normal soil). The highest percentage germination was in treatment $T_{3}$ containing vermicompost and $1 / 2$ recommended of NPK followed by treatment $\mathrm{T}_{2}$ containing full of recommended dose of NPK followed by treatment $T_{1}$ soil and vermiwash combination. Treatment $\mathrm{T}_{5}$ also improved seed germination. On analyzing the data (ANOVA two way) the treatment was non-significant at 5\% level $\left(\mathrm{F}_{\mathrm{cal}}<\mathrm{F}_{\mathrm{tab}}\right)$ (Table 1 and Fig. 1). The lowest seed germination was in treatment $\left(\mathrm{T}_{0}\right)$ in normal soil.

The present study evaluated seed germination percentage of okra due to vermicompost treated soil and Vermiwash. Vermicompost treated soil enhanced seed germination in comparison to control. In a similar study by Bhat and Limaye (2012) on Mirabilis jalapa, Calendula officenalis, Elitora ternatea recorded $100 \%$ seed germination after 7 days of sowing. Nadi et al., (2011) reported 91\% seed germination of pistachio as compare to control $(68.3 \%)$ by applying 10 to $20 \%$ vermicompost into the soil.

This may be due to the higher mineral contains present in vermicompost added soil. The increased the seed germination $88 \%$ was obtained in vermiwash treated soil as compare to vermicompost.

This may be due to the increased mineral contained and growth regulators produce by worms. Fatima and Seker (2014) studied growth promoting effect of vermiwash on germination of vegetable crops. It was reported that vermiwash at higher dilution is able to bring about increased germination rate and enhanced seedling growth. This effect can be attributed to the biofertilizer capability of vermiwasah as it possess as growth promoting effects.
Variation in plants height of okra (Abelmoschus esculentus L.) plants due to treatment of vermicompost

In present study the plant height was observed after 15 days, 30days, 45 days, 60 days and 75 days with different treatments of vermicompost. The maximum plant height was observed in $T_{3}$ which contained soil mixed with vermicompost and $1 / 2$ recommended dose of NPK. Treatment $\mathrm{T}_{3}$ increased plant height $117 \%$ compared with the treatment $\mathrm{T}_{1}$ containing soil and vermicompost. The height of okra plants increased from 30 to 45 days and 60 to 75 days. The lowest growth was observed in control treatment $\left(\mathrm{T}_{0}\right)$ containing normal soil only. The growth of the okra plants was enhanced when recommended dose of fertilizer (NPK) was added to the vermicompost treatment i.e., Treatment $\left(\mathrm{T}_{3}\right)$. Treatments were significant at $5 \%$ level $\left(\mathrm{F}_{\text {cal }}<\right.$ $F_{\text {tab}}$ ) (Table 2 and Fig. 2).

In the present study it was observed that vermicompost added to soil improved the height of okra plant. Kaur et al., (2015) also reported growth enhancement of okra shoot length at 30, 60 and 90 days in 50\% vermicompost concentration. In the present data plant height (shoot length) was influenced significantly $(\mathrm{P}<0.05)$ with the application of vermicompost and half dose of recommended inorganic fertilizer in the soil. Esakkiannal et al., (2015) reported similar trend of increased height (shoot length) of Dolichous lablab where plant height significantly increased over control. Vermicompost could serve as a naturally produced slow released source of plant nutrients. Therefore excellent growth was possible due to some plant growth promoting nutrients of vermicompost. Ghasem et al., (2014) studied effect of organic fertilizer on cucumber and observed $22.6 \%$ increase in plant length. The vermicompost improved porosity, soil water capacity, soil 
fertility that led to better okra plant growth. The vermicompost applications had greater effects on the height of okra plant. This may have been due to degradation of the vermicompost and microbial activity on exposure to sun and air.

Variation in plants height of okra (Abelmoschus esculentus L.) plants due to treatment of vermiwash

In this study vermicompost was prepared and vermiwash was developed from the prepared vermicompost. The prepared vermiwash was administered in the soil of pot experiment. The quantity of vermiwash was administered three times per pot was $100 \mathrm{ml}$ at 15 days interval. The best growth of okra plants was in the pot treatment $\mathrm{T}_{4}$ containing vermiwash $(100 \mathrm{ml})$ and half dose of recommended NPK at every 15 days intervals up to 75 days followed by the treatment $\mathrm{T}_{5}$ containing soil and vermiwash. The growth of the okra plant was rapid during 60 to 75 days and was significant (at 5\%). From the data in table 3 there was a slight increase $(3.93 \%)$ in the growth of okra plant as compared to control treatment containing normal soil only. The data obtained were analyzed using ANOVA two ways in which treatments were significant at every 15 days of interval and were significant (Table 3 and Fig. 3) during the first 15 days the growth of the okra plants was lower.

The assessment of vermiwash was done by foliar application at 10 days interval and observations were recorded at 15 days interval. The plant height after 15 days was maximum for treatment $\mathrm{T}_{4}$ containing half recommended dose of NPK and vermiwash followed by treatment $\mathrm{T}_{5}$ containing vermiwash liquid. The maximum height was due to chemical fertilizers with higher percentage of available salts (Nitrate, Phosphate and potassium) which significantly increased the plant growth (Ansari and
Sukhraj, 2010). The increased growth of okra may be due to the impact of microbes in biofertilizers (Lalithea et al., 2000) or due to presence of plant growth promoter like gibberellins, cytobinins and auxins (Krishnamoorthy and Vajranbhiah, 1986). Nath and Singh, (2009) also reported increased growth of okra due to vermiwash prepared from Dung and Rice bran. Esakkiammal et al., (2015) reported the shoot growth of Dolichous lablab due to combination of vermiwash and vermicompost.

Variation in Number of leaves of okra (Abelmoschus esculentus L.) plants due to treatment of vermicompost

The present investigation tested the efficacy of vermicompost on the growth of okra plant, number of leaves of okra plant was observed at 15 days of intervals. Number of leaves of plant doubled with the treatment of vermicompost mixed with soil and half recommended dose of NPK $\left(\mathrm{T}_{3}\right)$ by comparing treatment $T_{1}$ and $T_{3}$. It was observed that addition of NPK in half recommended dose increased number of leaves $29.55 \%$ with treatment $\left(\mathrm{T}_{1}\right)$ from the data obtained.

It was found that $59 \%$ increase in number of leaves with the treatment $\left(\mathrm{T}_{1}\right)$ containing vermicompost in comparison to the control treatment $\left(\mathrm{T}_{0}\right)$ containing normal soil. Within 15 days of time, the treatment $\mathrm{T}_{2}$ slightly increased number of leaves as compared to the treatment $T_{1}$ and $T_{3}$. Major effect was observed after 60 days where number of leaves increased significantly on analyzing the data using ANOVA treatment at 5\% level (Table 4 and Fig. 4).

In the present investigation different treatment of vermicompost in to the soil was given and the variation in number of leaves of okra plant was recorded after 15 days, 30days upto 75 days of sowing with soil and vermicompost. 
Table.1 Seed germination (\%) of Okra (Abelmoschus esculentus L.) plant due to Treatments after 7 days

\begin{tabular}{|c|c|}
\hline TREATMENTS & Germination (\%) \\
\hline$T_{0}$ - Normal Soil & 66.66 \\
\hline$T_{1}-$ Soil + Vermicomost & 77.77 \\
\hline$T_{2}-$ Soil + NPK RD 120:60:60kg/ha & 88.88 \\
\hline$T_{3}-$ Soil + $1 / 2$ RD of NPK + Vermicompost & 100.00 \\
\hline$T_{4}-$ Soil +1/2 RD OF NPK + Vermiwash & 77.77 \\
\hline$T_{5}-$ Soil+ Vermiwash & 88.88 \\
\hline F-test & NS \\
\hline Fcal & 1.41 \\
\hline Ftab & 2.22 \\
\hline S. Ed. $( \pm)$ & 135.33 \\
\hline C. D. $(5 \%)$ & 300.43 \\
\hline
\end{tabular}

Table.2 Variation in plants height of okra (Abelmoschus esculentus L.) plants due to vermicompost treatment

\begin{tabular}{|c|c|c|c|c|c|c|}
\hline \multicolumn{1}{|c|}{ TREATMIENTS } & \multicolumn{5}{|c|}{ Plants height of okra (cm) } \\
\hline & 15 Days & 30 Days & 45 Days & 60 Days & 75 Days \\
\hline$T_{0}$ - Normal soil & 4.33 & 10.30 & 17.83 & 25.83 & 33.00 \\
\hline$T_{1}$-Soil + Vermicompost & 7.00 & 11.83 & 21.33 & 30.83 & 41.00 \\
\hline$T_{2}$-Soil + NPK RD 120:60:60Kg/ha & 7.83 & 13.73 & 23.23 & 32.83 & 46.70 \\
\hline$T_{3}$-Soil +1/2 RD of NPk + Vermicompost & 8.83 & 14.33 & 31.33 & 47.66 & 89.66 \\
\hline F-test & S & S & S & S & S \\
\hline Fcal & 31.52 & 5.57 & 15.05 & 41.91 & 46.041 \\
\hline Ftab & 2.44 & 2.44 & 2.44 & 2.44 & 2.44 \\
\hline S.Ed. $( \pm)$ & 0.165 & 0.859 & 3.074 & 2.978 & 3.865 \\
\hline C.D.(5\%) & .1 .180 & 2.698 & 5.102 & 5.011 & 5.725 \\
\hline
\end{tabular}

Table.3 Variation in plants height of okra (Abelmoschus esculentus L.) plants due to Vermiwash treatment

\begin{tabular}{|c|}
\hline TREATMENTS \\
\hline $\mathrm{T}_{0^{-}}$Normal soil \\
\hline$\frac{T_{4}-\text { Soil + } 1 / 2 \text { RD of NPK + Vermiwash }}{T_{5}=\text { Soil + Vermiwash }}$ \\
\hline $\mathbf{T}_{5^{-}}$Soil + Vermiwash \\
\hline F-test \\
\hline Fcal \\
\hline Ftab \\
\hline S.Ed. $( \pm)$ \\
\hline C.D.(5\%) \\
\hline
\end{tabular}

\begin{tabular}{|l|c|l|l|l|}
\hline \multicolumn{7}{|c|}{ Plants height of okra } \\
\hline 15 Days & 30 Days & 45 Days & 60 Days & 75 Days \\
\hline 4.33 & 10.00 & 17.83 & 25.83 & 33.00 \\
\hline 7.43 & 12.63 & 20.04 & 29.33 & 39.00 \\
\hline 7.33 & 10.83 & 18.53 & 27.33 & 34.30 \\
\hline S & S & S & S & S \\
\hline 48.15 & 48.15 & 13.95 & 7.83 & 18.79 \\
\hline 2.77 & 2.77 & 2.77 & 2.77 & 2.77 \\
\hline 0.090 & 0.090 & 0.181 & 0.556 & 0.749 \\
\hline 0.996 & 0.996 & 1.414 & 2.461 & 2.850 \\
\hline
\end{tabular}


Table.4 Variation in Number of leaves of okra (Abelmoschus esculentus L.) plants due to vermicompost treatment

\begin{tabular}{|l|}
\hline \multicolumn{1}{|c|}{ TREATMENTS } \\
\hline $\mathrm{T}_{0}$ - Normal soil \\
\hline $\mathrm{T}_{1}-$ Soil + Vermicompost \\
\hline $\mathrm{T}_{2}-$ Soil + NPK RD $120: 60: 60 \mathrm{Kg} / \mathrm{ha}$ \\
\hline $\mathrm{T}_{3}-$ Sol + 1/2 RD of NPk + Vermicompost \\
\hline F-test \\
\hline Feal \\
\hline Ftab \\
\hline S.Ed. $( \pm)$ \\
\hline C.D.(5\%)
\end{tabular}

\begin{tabular}{|c|c|c|c|c|}
\hline \multicolumn{7}{|c}{ No. of leaves of okra plants } \\
\hline 15 Days & 30 Days & 45 Days & 60 Days & 75 Days \\
\hline 3.33 & 4.66 & 5.33 & 6.33 & 5.66 \\
\hline 5.00 & 7.33 & 6.66 & 7.66 & 9.00 \\
\hline 5.33 & 7.66 & 7.33 & 8.33 & 10.00 \\
\hline 5.00 & 8.33 & 8.66 & 10.33 & 11.66 \\
\hline S & S & S & S & S \\
\hline 12.57 & 21.53 & 29.71 & 25 & 27.64 \\
\hline 2.44 & 2.44 & 2.44 & 2.44 & 2.44 \\
\hline 0.091 & 0.170 & 0.091 & 0.156 & 0.327 \\
\hline 0.880 & 1.206 & 0.880 & 1.155 & 1.669 \\
\hline
\end{tabular}

Table.5 Variation in Number of leaves of okra (Abelmoschus esculentus L.) plants due to vermiwash treatment

\begin{tabular}{|c|l|l|l|l|l|l|}
\hline \multicolumn{1}{|c|}{ TREATMIENTS } & \multicolumn{5}{|c|}{ No. of leaves of okra plants } \\
\hline & 15 Days & 30 Days & 45 Days & 60 Days & 75 Days \\
\hline $\mathrm{T}_{0}$ - Normal soil & 3.33 & 4.66 & 5.33 & 6.33 & 5.66 \\
\hline $\mathrm{T}_{4}$-Soil + 1/2 RD of NPK + Vermiwash & 5.00 & 6.33 & 7.66 & 7.00 & 8.33 \\
\hline $\mathrm{T}_{5}$-Soil + Vermiwash & 5.00 & 5.66 & 6.00 & 6.66 & 8.00 \\
\hline F-test & $\mathrm{S}$ & $\mathrm{NS}$ & $\mathrm{S}$ & $\mathrm{NS}$ & $\mathrm{S}$ \\
\hline Feal & 25 & 2.23 & 13 & 0.25 & 27.64 \\
\hline Ftab & 2.77 & 2.77 & 2.77 & 2.77 & 2.77 \\
\hline S.Ed. $( \pm)$ & 0.052 & 0.445 & 0.156 & 0.628 & 0.327 \\
\hline C.D. $(\mathbf{5} \%)$ & 0.755 & 1.232 & 1.306 & 1.739 & 1.669 \\
\hline
\end{tabular}

Table.6 Variation in leaf surface area $\left(\mathrm{cm}^{2}\right)$ of Okra (Abelmoschus esculentus L.) plants due to vermicompost treatment after 75 days

\begin{tabular}{|l|}
\hline \multicolumn{1}{|c|}{ Treatments } \\
\hline $\mathbf{T}_{\mathbf{0}}$ - Normal Soil \\
\hline $\mathbf{T}_{1}$ - Soil + Vermicomost \\
\hline $\mathbf{T}_{2}$ - Soil + NPK RD 120:60:60kg/ha \\
\hline $\mathbf{T}_{3}-$ Soil + 1/2 RD of NPK + Vermicompost \\
\hline F-test \\
\hline Fcal \\
\hline Ftab \\
\hline S. Ed. $( \pm)$ \\
\hline C. D. $(5 \%)$
\end{tabular}

\begin{tabular}{|c|}
\hline Leaf area $\left(\mathrm{cm}^{2}\right)$ \\
\hline 28.33 \\
\hline 44.66 \\
\hline 50.66 \\
\hline 88 \\
\hline S \\
\hline 2368.93 \\
\hline 2.44 \\
\hline 0.379 \\
\hline 1.792 \\
\hline
\end{tabular}


Table.7 Variation in leaf surface area $\left(\mathrm{cm}^{2}\right)$ of Okra (Abelmoschus esculentus L.) plants due to treatment of vermiwash foliar spray after 75 days

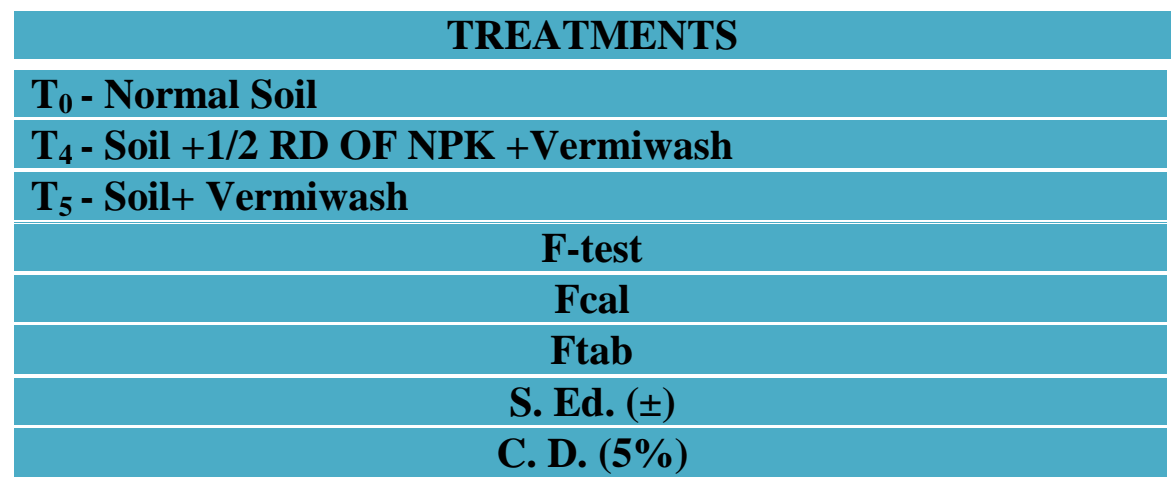

\begin{tabular}{|c|}
\hline leaf area $\left(\mathrm{cm}^{2}\right)$ \\
\hline 28.33 \\
\hline 43.66 \\
\hline 40.66 \\
\hline $\mathrm{S}$ \\
\hline 15.91 \\
\hline 2.77 \\
\hline 5.866 \\
\hline 7.997 \\
\hline
\end{tabular}

Plate.1 Earthworms (Eisenia foetida) collected from Krishi Vigyan Kendra (SHIATS)

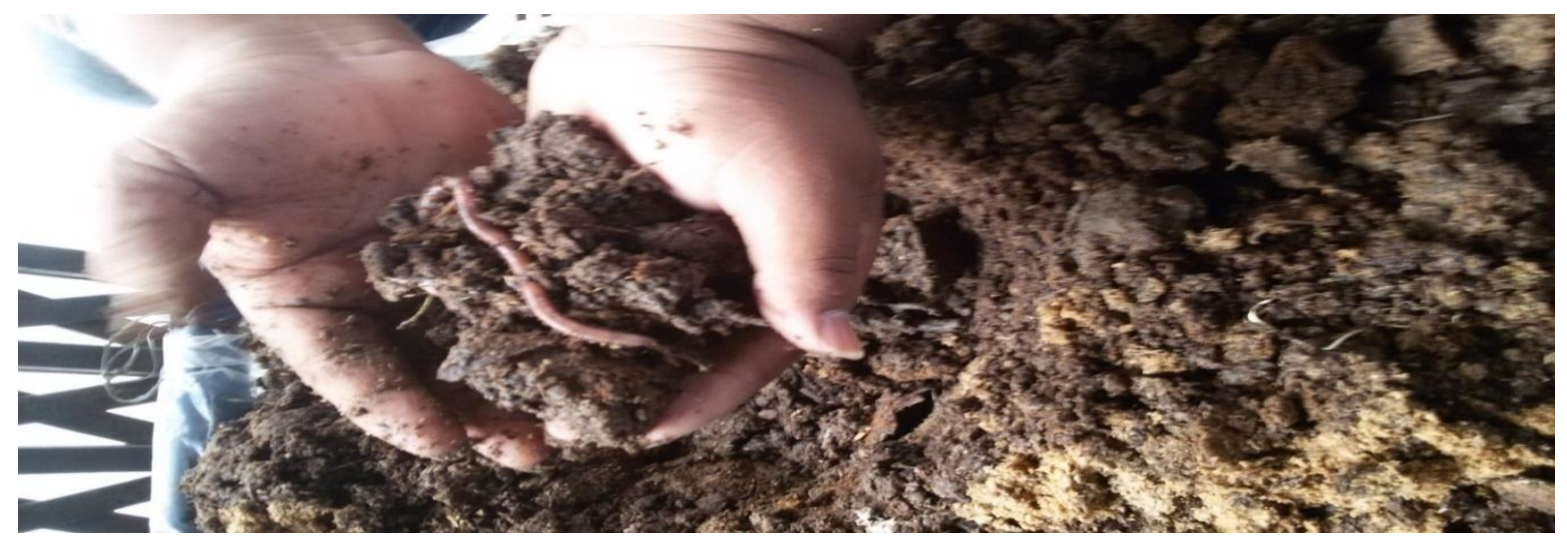

Plate.2 Different steps for preparation of Vermicompost
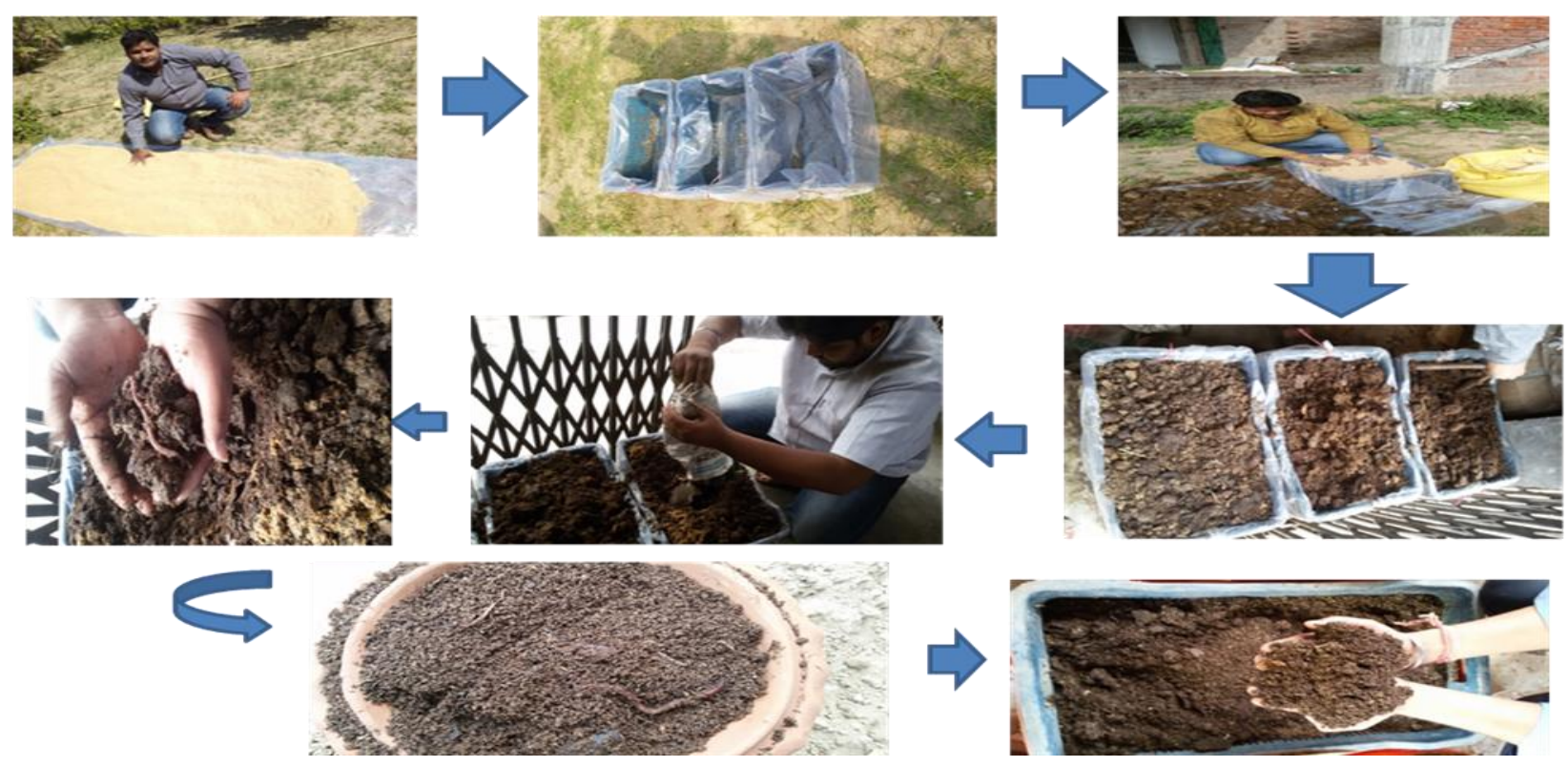
Plate.3 Collection of vermiwash extracted from vermicompost
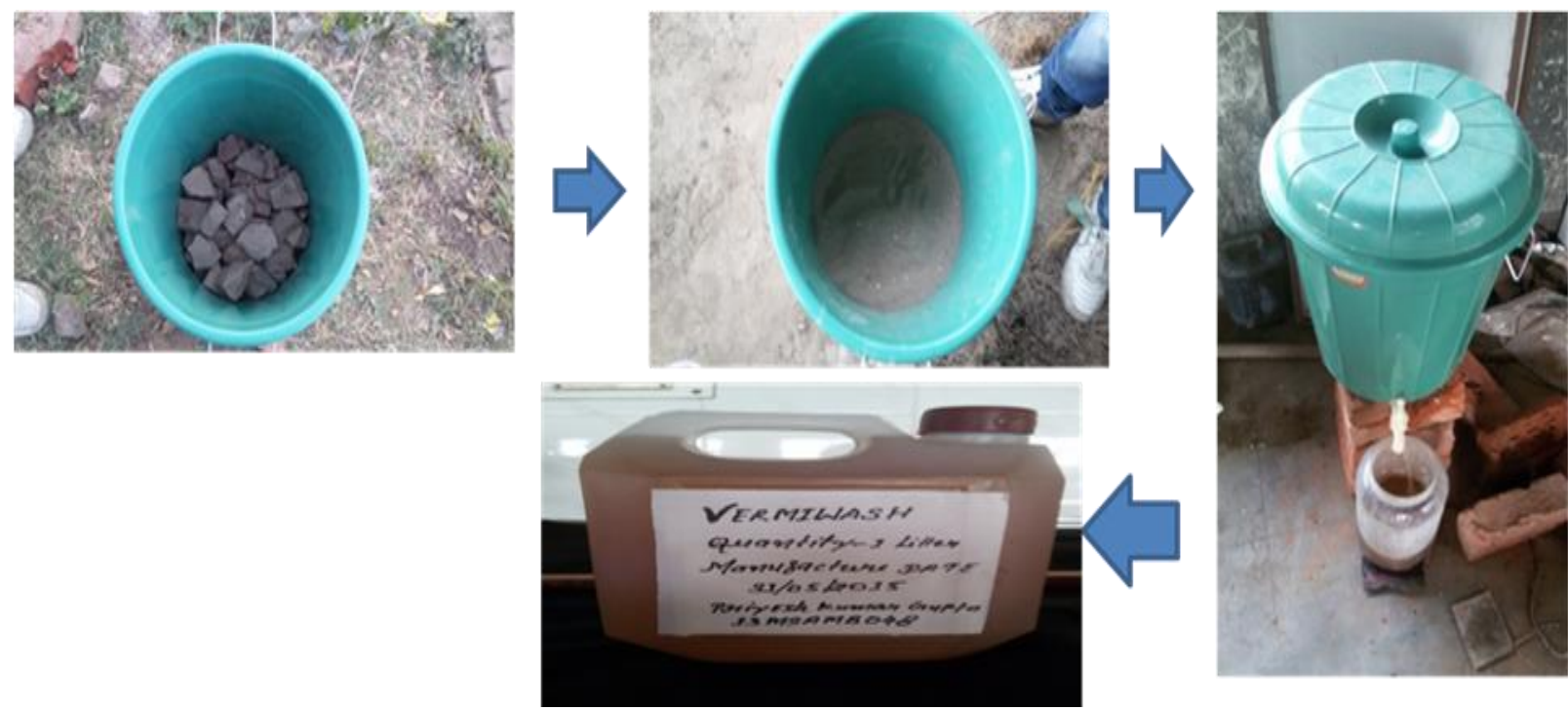

Plate.4 Growth measurement of Okra (Abelmoschus esculentus L.) plant due to various treatment of vermicompost and vermiwash
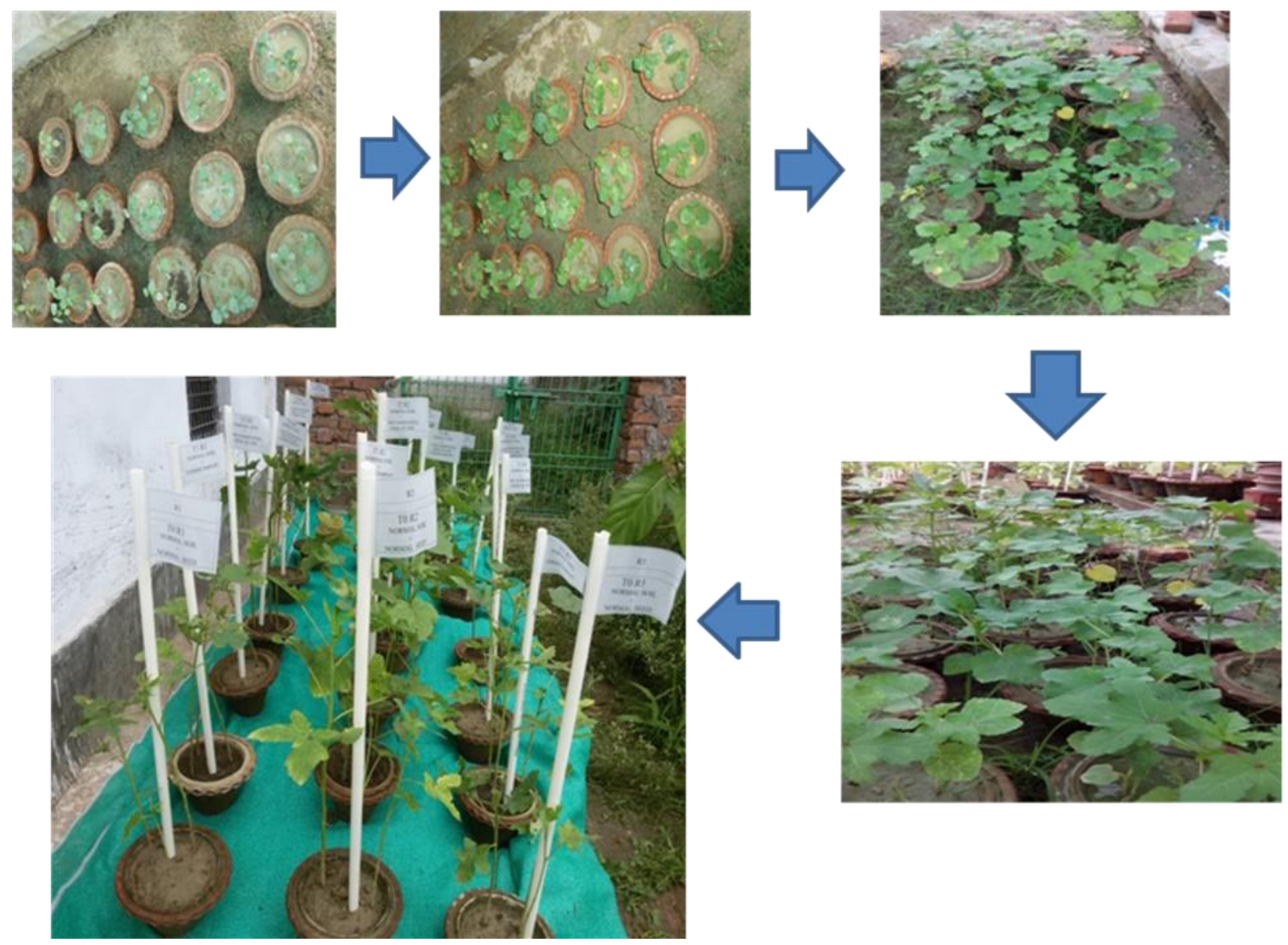
Fig.1 Seed germination (\%) of okra (Abelmoschus esculentus L.) plant after 7 days

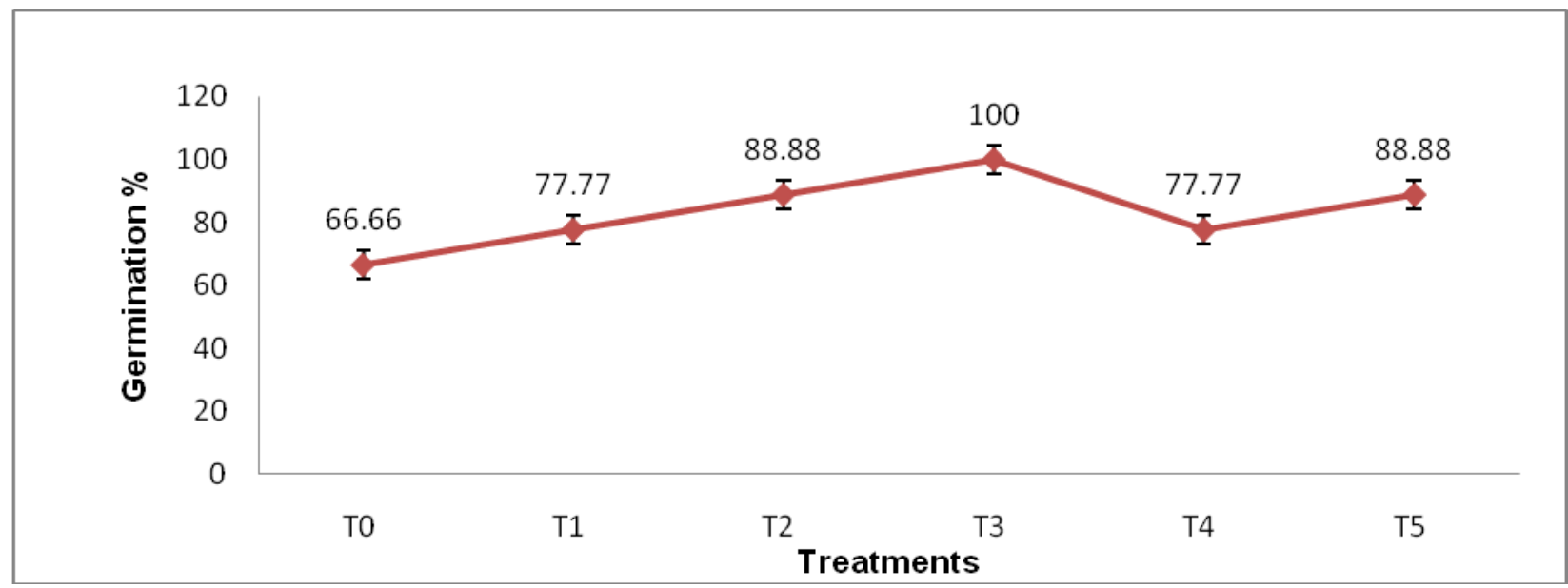

Fig.2 Effect of vermicompost on okra (Abelmoschus esculentus L.) plants height after 75 days

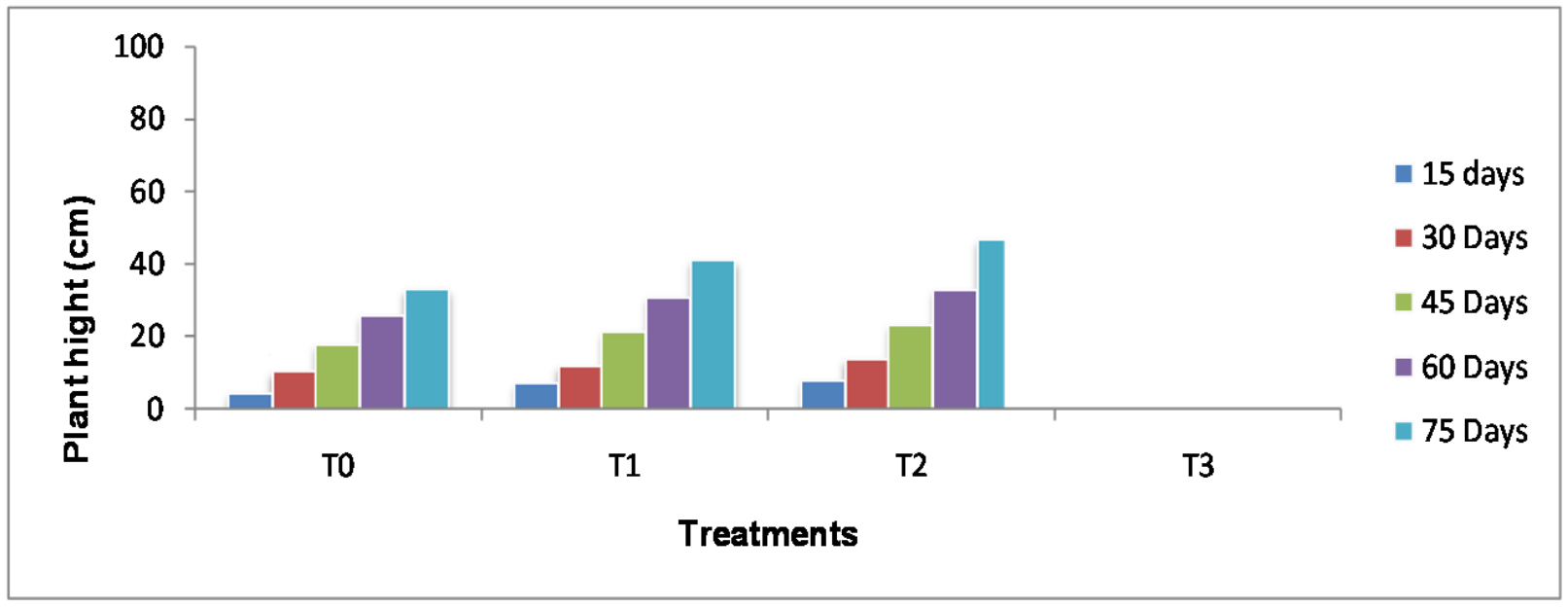

Fig.3 Effect of vermiwash foliar spray on okra (Abelmoschus esculentus L.) plants height after 75 days

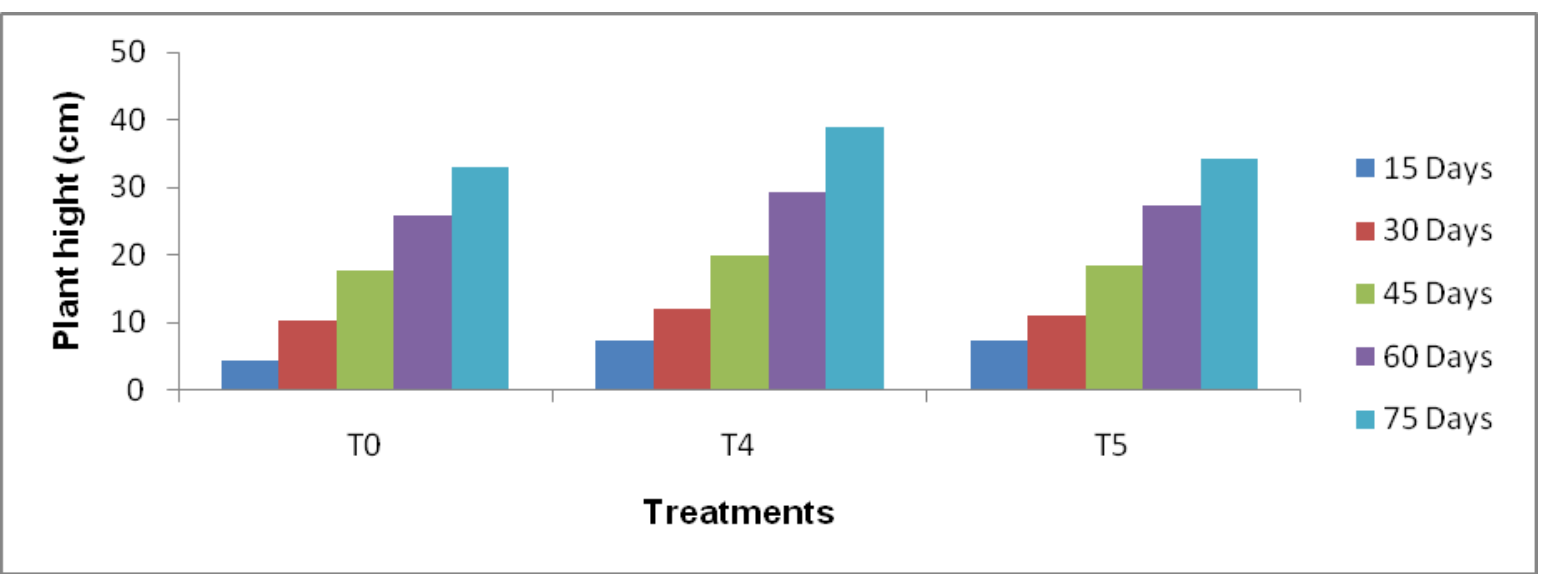


Fig.4 Effect of vermicompost on number of leaves of okra (Abelmoschus esculentus L.) plants after 75 days

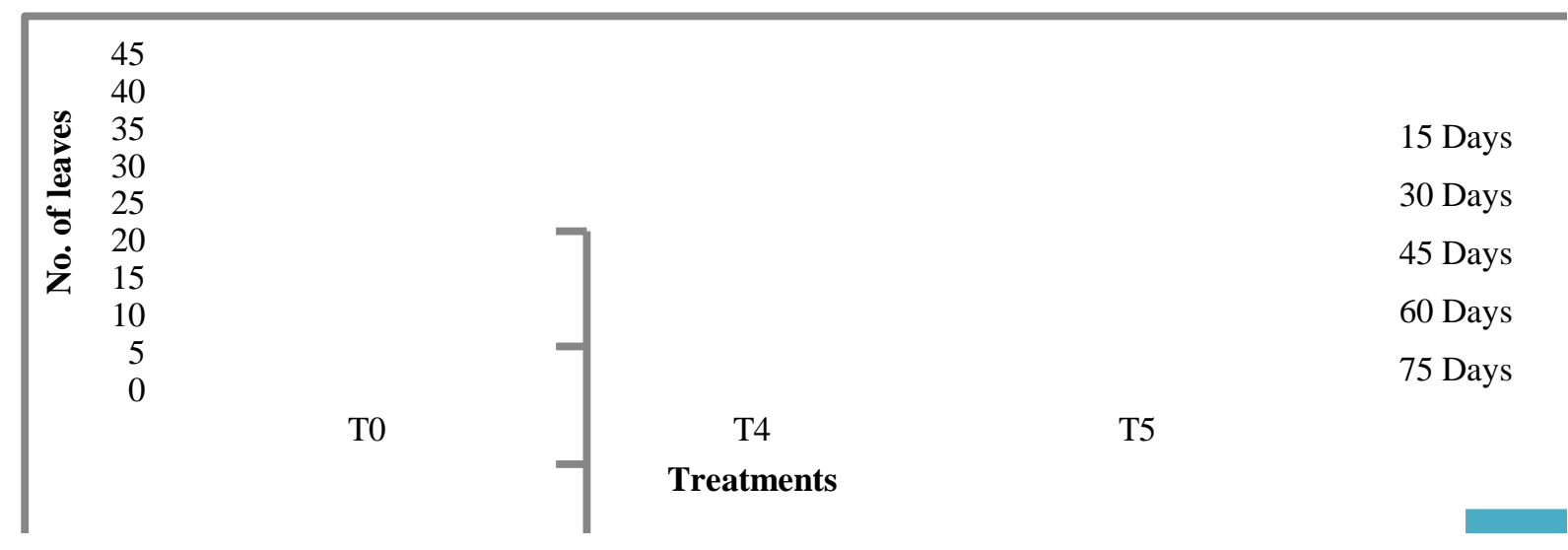

Fig.5 Effect of vermiwash foliar spray on number of leaves of okra (Abelmoschus esculentus L.) plants after 75 days

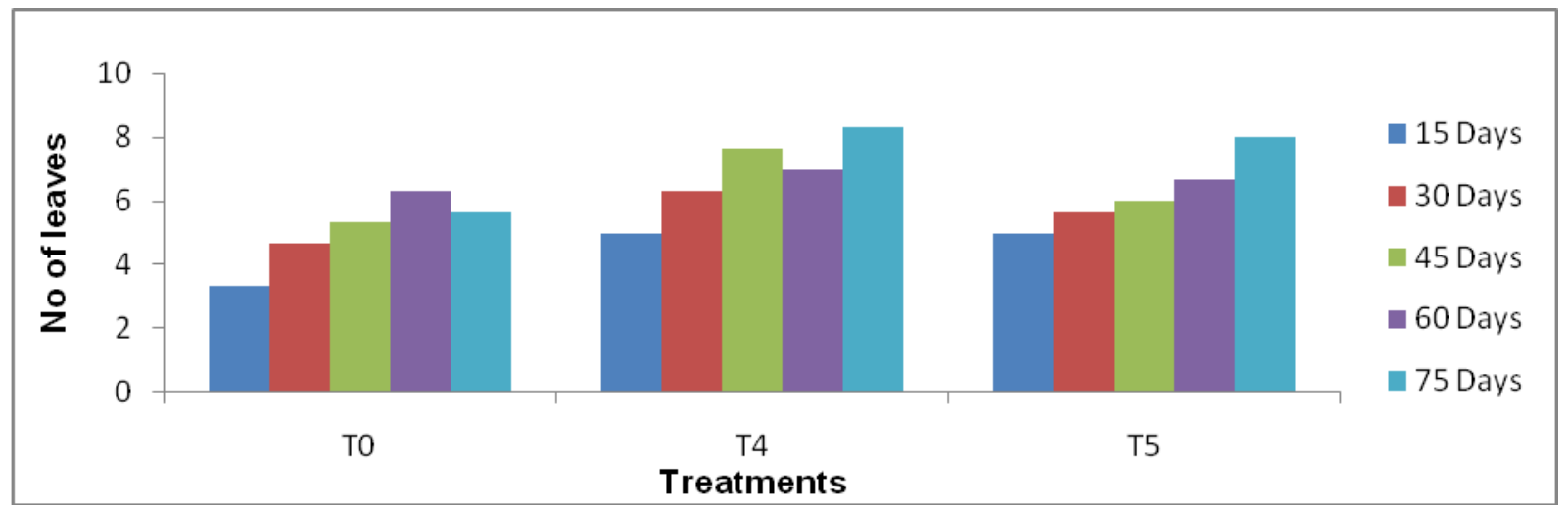

Fig.6 Effect of vermicompost on leaf surface area $\left(\mathrm{cm}^{2}\right)$ of okra (Abelmoschus esculentus L.) plant after 75 days

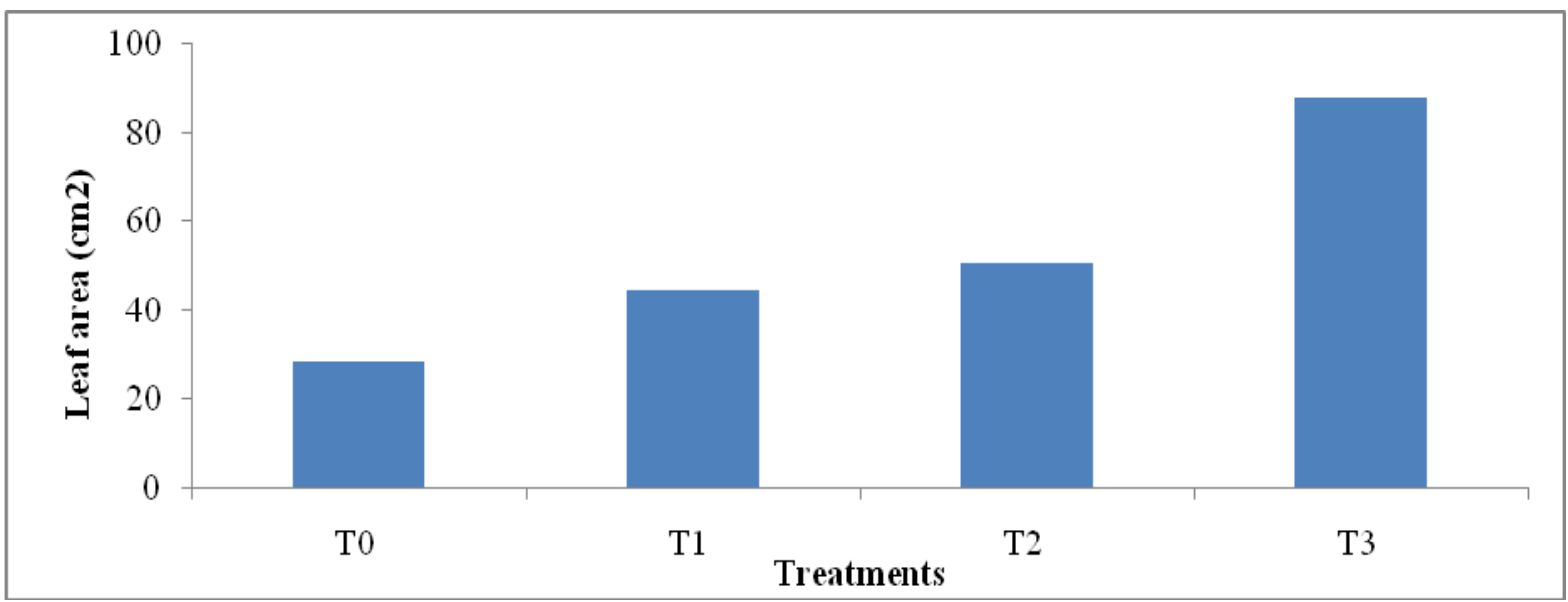


Fig.7 Effect of vermiwash foliar spray on leaf surface area $\left(\mathrm{cm}^{2}\right)$ of okra (Abelmoschus esculentus L.) plant after 75 days.

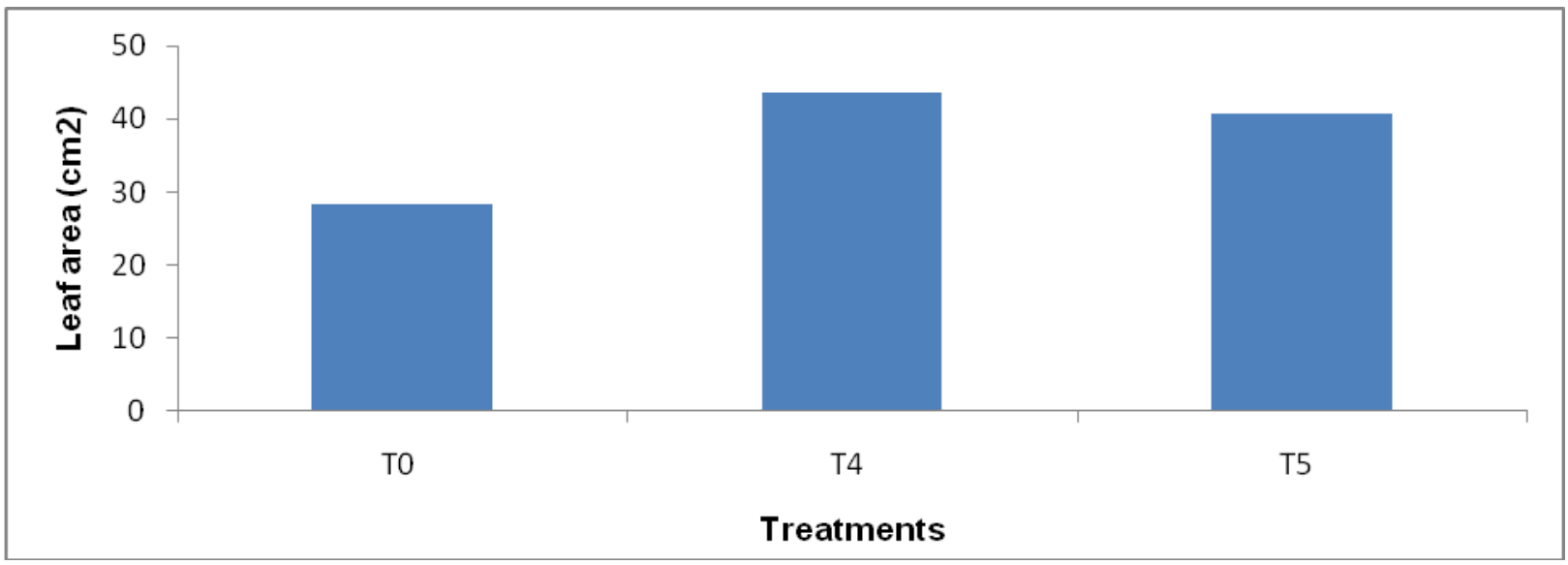

From the results with vermicompost and half dose of recommended inorganic fertilizer in soil gave highest number of the leaves of okra plants. Vermicompost amended soil also gave higher growth. Esakkiammal et al., (2015) also reported similar trend in number of leaves of okra plant. Attarde et al., (2012) also reported increased number of leaves of okra plant with various treatments of vermicompost in to soil. Bhat and Limaye (2012) reported enhancement of number of leaves at flowering stage of plants of Mirabilis jalapa, Calendula officinalis and Eliforia ternatea after 75 days sowing.

\section{Variation in Number of leaves of okra (Abelmoschus esculentus L.) plants due to different vermiwash treatments}

This study evaluated effect of various treatment of vermiwash on number of leaves of okra plant based on data in the table 5. The treatment $\left(\mathrm{T}_{4}\right)$ was best for the number of leaves increased by $47.17 \%$ in comparison to control treatment $\left(\mathrm{T}_{0}\right)$. The recommended dose of NPK had non-significant effect on number of leaves in comparison to the treatment $\left(\mathrm{T}_{5}\right)$ containing soil and vermiwash. Treatment $\left(\mathrm{T}_{4}\right)$ enhanced the number of leaves from 45 days to 75 days. Statistically the treatment found significant at 5\% level
(Table 5 and Fig. 5). The present investigation was conducted to assess the vermiwash prepared from manure and Rice bran waste vermicompost on the number of leaves of okra plant. The observations were recorded at 15 days of interval upto 75 days with the treatment of vermiwash and vermiwash with $1 / 2$ dose of chemical fertilizers. The number of leaves observed after 15 days of sowing was maximum for plants treated with vermiwash and NPK followed by the treatment $T_{6}$ containing vermiwash only. Ansari and Sukhlaj (2010) also reported maximum number of leaves observed in okra plant treated with chemical fertilizers followed by vermiwash and vermicompost.

The maximum number of leaves observed with $\mathrm{T}_{4}$ (NPK + Vermiwash) was accounted for chemical fertilizers high in nitrogen. This is responsible for rapid plant growth. Vermiwash was also enriched in certain metabolite and vitamins that belong to the $\mathrm{B}$ group or provitamins $\mathrm{D}$ which help to enhance plant growth (Lalitha et al., 2000; Ansari 2000 a, b). Number of leaves of Dolichous lablab was also found to be increased due to treatment of vermiwash and vermicompost which may be due to the nutrient rich fluid with components promoting good plant growth. Weerasinghe et al., (2006) 
suggested that vermiwash is a natural growth supplement for tea, coconut and horticultural crops.

Variation in leaf surface area $\left(\mathrm{cm}^{2}\right)$ of Okra (Abelmoschus esculentus L.) plants due to vermicompost treatment after 75 days

The present study was conducted to test the effectiveness of various treatment of vermicompost on the leaf surface area of okra plant. In this investigation treatment $\left(\mathrm{T}_{3}\right)$ was most effective $\left(88 \mathrm{~cm}^{2}\right)$ after 75 days, followed by treatment $\mathrm{T}_{2}$ containing soil and NPK dose followed by treatment $\left(T_{1}\right)$ containing soil mixed with vermicompost $(1: 1)$. The leaf surface area increased significantly from an average $44.66 \mathrm{~cm}^{2}$ to 88 $\mathrm{cm}^{2}$ by adding half recommended dose of NPK. The combination of vermicompost and $1 / 2$ NPK dose enhanced the leaf surface area three times in comparison to the normal soil. The observed data were analyzed statistically using ANOVA the treatment and found significant at 5\% level (Table 6 and Fig. 6).

The present study was conducted to evaluate the effect of various treatments of vermicompost on leaf area of okra plant. The observation of leaf surface area was recorded after 75 days of sowing. Similar trend of enhancement of leaf surface area was reported by Attarde et al., (2012). In a similar study conducted by Nadi et al., (2011) leaf surface area $\left(\mathrm{cm}^{2}\right)$ of Pistachio increased by different vermicompost with Pistachio vermicompost, Cotton vermicompost and cow manure vermicompost. These authors reported that only $10 \%$ and $20 \%$ amendment increased the leaf surface area. Therefore addition of vermicompost to soil resulted in increased mineral content in subtract. Arancon et al., (2005) reported that soil treated with vermicompost had significantly higher microbial biomass than soil treated with in organic fertilizers only. There was a trend for greater dehydrogenase activity occurring in soils treated with vermicompost. The authors (Arancon et al., 2005) also reported that soils treated with vermicompost had significantly greater amount of orthophosphates which enhanced the growth of the plants.

Variation in leaf surface area $\left(\mathrm{cm}^{2}\right)$ of Okra (Abelmoschus esculentus L.) plants due to treatment of verminwash foliar spray after 75 days

In this investigation various treatments of vermiwash were used for assessing the growth of the okra plant. Leaf surface area was observed with treatment of vermiwash, $100 \mathrm{ml}$ of vermiwash was administered thrice at 10 days interval. The leaf surface area was observed at 15 days interval up to 75 days from the data in table 7 . Treatment $\left(\mathrm{T}_{4}\right)$ yielded maximum leaf area followed by treatment $\mathrm{T}_{5}$ containing vermiwash only. Treatment $\mathrm{T}_{4}$ containing half recommended dose of NPK and vermiwash increased leaf area up to $43.66 \mathrm{~cm}^{2}$ in comparison to the control treatment $\left(\mathrm{T}_{0}\right)$ containing normal soil (leaf surface area $28.3 \mathrm{~cm}^{2}$ ). It was inferred that recommended dose of fertilizer had lower effect on number of leaves of okra plant while using vermiwash, upon analyzing the data using ANOVA, the treatments found significant at 5\% level (Table 7 and Fig. 7).

In the present study maximum leaf surface area was in the treatment containing soil and half dose NPK and foliar application of vermiwash. Elumalai et al., (2013) reported that vermiwash exhibited growth promoting effects on the exomorphological characters such as plant height, length and diameters, number of leaves and leaf surface area of Abelmoschus esculantus. Among the various foliar treatments used in the study $15 \%$ vermiwash showed growth enhancing effects. Esakkiammal et al., (2015) also reported 
increased length of leaves of Dolichous lab lab when soil was amended with vermicompost and vermiwash. The treatment $\mathrm{T}_{4}$ and $\mathrm{T}_{5}$ was highly significant improving soil's physical and chemical properties. The increased leaf area of okra might be due to improved trace element content of soil. However combination of vermiwash and chemical fertilizer was highly effective in improving soil macronutrients and micronutrients.

According to Lalitha et al., (2000) application of organic fertilizers had an emphatic effect on the plant growth and production, indicating a better performance of okra using vermiwash and combination of vermiwash and chemical fertilizers. The results are in agreement with Ansari and Sukhraj (2010).

It is concluded from the present investigation that Vermicompost and vermiwash were a plant growth promoting organic fertilizers that efficiently improved the growth of Okra (Abelmoschus esculantus L).

Among the five treatments $T_{3}$ (Soil $+1 / 2$ recommended dose of NPK + Vermicompost) was highly effective in case of seed germination, plant height, number of leaves/plant, leaf area index $\left(\mathrm{cm}^{2}\right)$ of okra (Abelmoschus esculantus L.). With the advent of modern high yielding varieties of okra, emphasis has been given mainly on use of chemical fertilizers neglecting the organic manures resulting in the deficiency of several macro and micronutrients.

The current world energy crisis and consequent price hike of fertilizers (due to withdrawal of subsidy) on fertilizers coupled with low purchasing power by farming community warrants the search for alternate nutrient sources. Therefore proper use of biofertilizer will improve the soil health and help in maximizing seed production.

\section{Statistical analysis}

The effect of all the treatments of vermicompost and vermiwash on okra plant growth was recorded in triplicates. The data were analyzed statistically. All the data were mean \pm SE of 3 replicates. The two way analysis of variance (ANOVA) was used to analyze the level of significance (Sokal and Rohlf, 1973).

\section{References}

Al-Dahmani, J. H., Abbasi, P. A., Miller, S. A. and Hoitink, H. A. J. (2003). Suppression of bacterial spot of tomato with foliar sprays of compost extracts under green house and field conditions. Journal of Plant Disease. 87: 913-919.

Anand, J. A., Wilson, M. D. P. and Kale, R. D. (1995). Effect of vermiwash on seed germination and seedling growth. Journal of Soil Biology and Ecology. 15: 90-95.

Ansari, A. A. (2008a). Effect of vermicompost and vermiwash on the productivity of spinach (Spinacia oleracea), Onion (Allium cepa) and Potato (Solanum tuberosum). World Journal of Agriculture Science. 4(5): 554-557.

Ansari, A. A. (2008b). Effect of vermicompost on the productivity of potato (Solanum tuberosum), spinach (Spinacia oleracea) and Turnip (Brassica campestris). World Journal of Agriculture Science. 4(3): 333-336.

Ansari, A. A. and Sukhraj, K. (2010). Effect of vermiwash and vermicompost on soil parameters and productivity of okra (Abelmoschus esculentus) in Guyana. Pakistan Journal of Agriculture Research. 23: 137-142.

Atiyeh, R. M., Subler, S., Edwards, C. A. and Metzger, J. D. (1999). Growth of tomato plant in horticulture potting 
media with vermicompost. Pedobiologia. 43: 1-5.

Attarde, S. B., Narkhede, S. D., Partil, R. P. and Ingle, S. T. (2012). Effect of organic and inorganic fertilizers on the growth and nutrient content of Abelmoschus esculentus (okra crop). International Journal of Current Research. 4(10): 137-140.

Barakan, F. N., Salem, S. H., Heggo, A. M. and Bin-Shiha, M. A. (1995). Activities of rhizosphere microorganisms as affected by application of organic amendments in a calcareous loamy soil Nitrogen transformation. Arid Soil Research and Rehabilitation. 9(4): 467480.

Beltran, E. M., Miralles, de-Imperial, R., Porcel, M. A., Delgado, M. M., Beringola, M. L. and Bigeriego, M. (2002). Effect of sewage sludge compost application on ammonium nitrogen and nitrate-nitrogen content of an Olive Grove soils. Proceedings the Journal of International Soil Conservation Organization Conference. 26-31.

Berry, S. K., Kalra, C. L. and Schyal, R. C. (1988). Quality characteristics of seeds of five okra (A. esculentus [L.] Moench) cultivars. Journal of Food Science and Technology. 25: 303.

Bhat, M. R. and Limaye, S. R. (2012). Nutrient status and plant growth promoting potential of prepared vermicompost. International Journal of Environmental Sciences. 3(1): 312-321.

Buckerfield, J. C., Flavel, T., Lee, K. E. and Webster, K. A. (1999). Vermicompost soil and liquid form as plant growth promoter. Pedobiologia. 42: 753-759.

Bwamiki, D. P., Zake, J. Y. K., Bekunda, M. A, Woomer, P. L., Bergstrom, L. and Kirchman, H. (1998). Use of coffee husks as an organic amendment to improve soil fertility in Ugandan banana production. Carbon and nitrogen dynamics in natural and agricultural tropical ecosystem. Pp. 113-127.

Carmody, F. and Collier, J. (1979). Vermicomposting as an alternative and innovative technology for sludge management. Journal of United States of America. 16(2): 29-31.

Domínguez, J. (2004). State of the art and new perspectives on vermicomposting research, in: Edwards, C.A. (Ed.) (1983), Earthworm Ecology (2nd edition), CRC Press, Boca Ratón, 401424.

Edwards, C. A. and Burrows, I. (1988). The potential of earthworm composts as plant growth media. In Earthworms in Environmental and Waste Management. Ed. C. A., Neuhauser, SPB Academic Publ. b.v. The Netherlands. 211-220.

Edwards, C. A., (1998). The use of earthworms in the breakdown and management of organic wastes. In: Edwards, C.A. (Ed.), Earthworm Ecology. CRC Press, Boca Raton, FL. 327-354.

Esakkiammal, B., lakshmibai, L. and Sornalatha. (2015). Studies on the combined effect of vermicompost and vermiwash prepared from organic waste by earth worms on the growth and yield parameters of Dolichous lab lab. Assian Journal of Pharmaceutical Science and Technology. 5(4): 246-252.

Fathima, M. and Sekar, M. (2014). Studies on growth on promoting effect of vermiwash on the germination of Vegetable Crops. International Journal of Current Microbiology and Applied Sciences. 3(6): 564-570.

Follet, R., Donahue, R. and Murphy, L. (1981). Soil and Soil Amendments. Prentice-Hall, Inc., New Jersey.

Ghasem, S., Morteza, A. S. and Maryam, T. (2014). Effect of organic fertilizer on cucumber (Cucumis sativus) yield. 
International Journal of Agriculture and Crop Sciences. 7(11): 808-814.

Graff, O. (1981). Preliminary experiment of vermicomposting of different waste materials using Eudrilus eugeniae Kingberg; In: M. Appelh of (ed.) Proc. of the workshop on 'Role of Earthworms in the Stabilization of Organic Residues'; Malanazoo Pub. Michigan, USA.179-191.

Grappelli, A., Galli, E. and Tomati, U. (1987). Earthworm casting effect on Agaricusbisporus fructification. Agrochemica. 21: 457-416.

Grundon, N. J. (1980). Effectiveness of soil dressing and foliar spray of copper sulphate in correcting copper deficiency of wheat (Triticuma estivum) in Queensl and. Australian Journal of Experimental Agriculture and Animal Husbandry. 20: 717-723.

Karuna, K., Patil, C. R., Narayanswamy, P. and Kale, R. D. (1999). Stimulatory effect of earthworm body fluid (vermiwash) on crinkle red variety of Anthurium andreanumlind. Journal of Crop Research. 17(2): 253-257.

Kaur, P., Bhardwaj, M. and Babbar, I. (2015). Effect of vermicompost and vermiwash on growth of vegetables. Research Journal of Animal, Veterinary and Fishery Sciences. 3(4): 9-12.

Krishnamoorthi, R. V. and Vajranabhiah, S. N. (1986). Biological activity of earthworms cast: An assessment of plant growth promoter levels in casts. Proceeding of the Indian Academy of Science (Animal science). 95: 341-350.

Lalitha, R., Fatima, K. and Ismail, S. A. (2000). The impact of biopesticide and microbial fertilizers on productivity and growth of Abelmoschus esculentus. Vasundara the Earth. 1(2):4-9

Marschner, H. (1995). Mineral nutrition of Higher Plants, Academic Press; London, U.K.
Monroy, F., Aira, M., Domínguez, J. and Velando, A. (2006). Seasonal population dynamics of Eisenia fetida (Savigny, 1826) (Oligochaeta, Lumbricidae) in the field. Comptes Rendus Biologies. 329: 912-915.

Nadi, M., Golchin, A., Mozafari, V., Saeidi, T. and Sedaghati, E. (2011). The effects of different vermicomposts on the growth and chemical composition of the pistachio seedlings. Journal of Research in Agriculture Science. 7: 59-69.

Nakasone, A. K., Bettiol, W. and de Souza, R. M. (1999). The effect of water extracts of organic matter on plant pathogens. Summa Phytopathologica. 25: 330- 335.

Nath, G. and Singh, K. (2009). Utilization of vermiwash potencial on certain summer vegetable crops. Journal of Central European of Agriculture. 10: 417-426.

Pascual, J. A., Garcia, C., Hernandez, T. and Ayuso, M. (1997). Changes in the microbial activity of an arid soil amended with urban organic wastes. Journal of Biology and Fertility of Soils. 24(4): 429-434.

Schippers, R. R. (2000). African indigenous vegetables- An overview of the cultivated species. 103-118.

Shield and Earl, B. (1982). Raising Earthworms for Profit. Shields Publication. P.O. Box 669 Eagle River Wisconsin. 128.

Siemonsma, J. S. and Kouame, C. (2004). Vegetable. Plant Resource of Tropical Africa 2. PROTA Foundation. Wageningen, Netherlands. 21-29.

Sokal, R. R. and Rohlf, F. J. (1973). Introduction to biostatistics. Freeman WH, San Francisco, 165, 231, 289.

Tindall, H. D. (1983). Vegetables in the tropics, Macmillan Press Ltd., London and Basingstoke. 325- 328.

Tomati, U., Grappelli, A. and Galli, E. (1987). The presence of growth regulators in earthworm-worked wastes. In: 
Bonvicini Paglioi, A.M. and Omodeo, P., (eds) On Earthworms. Proceedings of International Symposium on Earthworms. 423-435.

Weersinghe, K. L. K., Mohotti, K. M., Herath, C. N., Sanarajeewa, A., Liyangunawardena, V. and Hitinayake, H. M. G. S. B. (2006). Biological and chemical properties of vermiwash a natural Plant growth supplement for tea, coconut and horticulture crops. Forestry and Environment Symposium,
University of Jayewardenepura, Sri Lanka. 246-252.

Werner, M. and Cuevas, R. (1996). Vermiculture in Cuba. Biocycle. Emmaus, PA., JG Press. 37: 61-62.

Zink, T. A. and Allen, M. F. (1998). The effects of organic amendments on the restoration of a disturbed coastal sage scrub habitat. The Journal of The society for Ecological Restoration. 6(1): $52-58$.

\section{How to cite this article:}

Priyesh Kumar Gupta, Ajay Kumar Singh, Jane C. Benjamin, Harison Masih, Ankit Singla, Surendra Kumar Ojha and Ramteke, P.W. 2018. Study of Vermicompost and Vermiwash Produced from Cow Manure and Rice Bran Waste on the Physiological Growth of Abelmoschus esculentus L. Int.J.Curr.Microbiol.App.Sci. 7(08): 1447-1464. doi: https://doi.org/10.20546/ijcmas.2018.708.166 